\title{
ANALISA FAKTOR PRILAKU HIDUP BERSIH DAN SEHAT (PHBS) DI WILAYAH KERJA PUSKESMAS SIMPANG IV SIPIN KOTA JAMBI TAHUN 2017
}

\author{
Laily Husna $^{7}$
}

\begin{abstract}
One of methods to control the distribution of diseases is through effective preventive programs. The Clean and Healthy Living Behaviour (PHBS) is often used for preventive action by controlling the community behaviour to minimize the interaction between human and agents. The implementation of PHBS accounted for 43,40\% in Province of Jambi. According to the data from Ministry of Health, thr national implementation of PHBS amongst household was 54,85\% and 53,89\% in 2010 and 2011 respectively. This research is an analytical study using cross sectional design. Thr study aims to identify determinant factors associated with community behaviour. Analytical survey refers to a study which deeply explore how and why the health phenomenon occurs. This is later analysed using correlation and phenomenon dynamic analysis. The research indicates that there is no significant correlation among educational degree, income, family member, knowledge and attitude towards clean and healthy living behavior. After conducting the test, however, the educational degree, income, family members, and attitute are indicated as counfounding factors. It is recommended that inter sectoral collaborative works are essentially required in order to develop community empowernment, particularly using media and participatory action method to apply healthy behaviour.
\end{abstract}

Keyword: Factor Analysis, The Clean and Healthy Living Behaviour

\section{PENDAHULUAN}

Kesehatan merupakan hak asasi manusia dan sekaligus merupakan investasi sumber daya manusia, serta memiliki kontribusi yang besar untuk meningkatkan Indeks Pembangunan Manusia (IPM). IPM adalah indeks yang mengukur pencapaian keseluruhan negara. Pencapaian ini meliputi 3 indikator yaitu tingkat pendidikan, derajat kesehatan dan kemampuan ekonomi masyarakat. Pemeliharaan kesehatan masyarakat akan memacu produktifitas kinerja masyarakat sehingga dapat meningkatkan kesejahteraan masyarakat. Oleh karena itu menjadi suatu keharusan bagi semua pihak untuk memelihara,

\footnotetext{
${ }^{7}$ Dosen Program Studi Keperawatan Akper Jambi
} 
meningkatkan dan melindungi kesehatan demi kesejahteraan seluruh masyarakat Indonesia (Dinkes, 2010).

Kejadian penyakit maupun gangguan kesehatan pada manusia tidak terlepas dari peran faktor lingkungan. Manajemen penyakit berbasis wilayah harus dilakukan secara terpadu dan pelaksanaannya dilakukan mengacu kepada teori simpul, yakni adanya keterpaduan antara pengendalian sumber penyakit, media transmisi, dan pengendalian faktor resiko kependudukan serta penyembuhan kasus penyakit pada suatu wilayah komunitas tertentu (Achmadi, UF,2008).

Menteri Kesehatan Republik Indonesia telah membuat Pedoman Pembinaan Perilaku Hidup Bersih dan Sehat yang tertuang dalam Peraturan Menteri Kesehatan Republik Indonesia Nomor: 2269/MENKES/PER/XI/2011 yang mengatur upaya peningkatan perilaku hidup bersih dan sehat atau disingkat PHBS diseluruh Indonesia dengan mengacu kepada pola manajemen PHBS, mulai dari tahap pengkajian, perencanaan, dan pelaksanaan serta pemantauan dan penilaian. Upaya tersebut dilakukan untuk memberdayakan masyarakat dalam memelihara, meningkatkan dan melindungi kesehatannya sehingga masyarakat sadar, mau, dan mampu secara mandiri ikut aktif dalam meningkatkan status kesehatannya.

Pemberdayaan masyarakat harus dimulai dari rumah tangga atau keluarga, karena rumah tangga yang sehat merupakan aset atau modal pembangunan dimasa depan yang perlu dijaga, ditingkatkan dan dilindungi kesehatannya. Beberapa anggota rumah tangga mempunyai masa rawan terkena penyakit menular dan penyakit tidak menular. oleh karena itu, untuk mencegah penyakit tersebut, anggota rumah tangga perlu diberdayakan untuk melaksanakan PHBS (Depkes,2013).

Dari buku penuntun hidup sehat (2010) lebih dari separuh jenis penyakit dan kematian pada anak dan balita disebabkan oleh kuman yang masuk ke dalam mulut melalui makanan, air, dan tangan yang kotor. Buruknya kebersihan seseorang dan kesehatan lingkungan termasuk persediaan air bersih mengakibatkan $88 \%$ kematian anak di seluruh dunia disebabkan karena terkena diare. Penyakit-penyakit tersebut dapat dicegah dengan menjaga kebersihan diri dan kesehatan lingkungan dengan cara buang air besar di jamban, mencuci tangan dengan sabun dan air sesudah buang air besar, membersihkan tinja anak, sebelum memberikan makan anak atau menyentuh makanan.

Data profil kesehatan Indonesia tahun 2015 menyebutkan bahwa baru $64,1 \%$ sarana yang telah dibina kesehatan lingkungannya, yang meiputi institusi pendidikan $(67,52 \%)$, tempat kerja $(59,15 \%)$, tempat ibadah $(58,84 \%)$, fasilitas kesehatan $(77,02 \%)$ dan sarana lain $(62,26 \%)$. Hal ini menunjukkan bahwa pembinaan PHBS ditatanan 
institusi pendidikan, tatanan tempat kerja, tatanan tempat umum dan tatanan fasilitas kesehatan juga masih belum berjalan sebagaimana mestinya.

Provinsi Jambi dalam pencapaian rumah tangga ber PHBS adalah sebesar 43,40\%. Pada data kementerian kesehatan tahun 2010 dan 2011 presentase rumah tangga yang melaksanakan Perilaku Hidup Bersih dan Sehat (PHBS) yang pada tahun 2010 targetnya adalah 50\% dan dalam pencapaiannya 54,85\% sedangkan, pada tahun 2011 target rumah tangga yang ber-PHBS adalah sebanyak 55\% dan dalam pencapaiannya hanya 53,89\%.Untuk mencapai target PHBS di Rumah Tangga, Pusat Promosi Kesehatan telah melakukan kemitraan, salah satunya dengan tim penggerak PKK yang mempunyai kewenangan serta jajaran sampai ketingkat desa/kelurahan bahkan sampai ketingkat rumah tangga melalui dasawisma. Metode yang digunakan berupa diskusi interaktif untuk membahas permasalahan tentang kegiatan pembinaan dan penilaian PHBS Rumah Tangga beserta upaya mengatasinya, pameran atau ekspose dokumentasi kegiatan promosi/pembinaan PHBS di Rumah Tangga (Profil Dinkes Provinsi Jambi, 2011).

Berdasarkan data dari Dinas Kesehatan kota Jambi tahun 2014 menunjukkan bahwa jumlah Rumah Tangga Yang berprilaku hidup bersih dan sehat masih kurang dari 50\%, salah satu kelurahan di provinsi Jambi yang memiliki PHBS rendah adalah diwilayah kerja Puskesmas Simpang IV Sipin. Data Dinas Kesehatan Kota Jambi menyebutkan dari jumlah rumah tangga yang dipantau tahun 2015 sebanyak 840 rumah tangga yang memiliki PHBS baik dan pada tahun 2016 hingga 2017 sebanyak 640 dan rumah tangga yang ber PHBS baik. Dari data tersebut dari 2015 hingga 2017 PHBS rumah tangga di wilayah kerja Puskesmas Simpang IV Sipin masih kurang dari 50\%. (Data Puskesmas Simpang IV Sipin).

Banyak faktor yang mempengaruhi perilaku hidup bersih dan sehat dimasyarakat yaitu menurut Lawrence Green menganalisis bahwa faktor perilaku sendiri ditentukan oleh tiga faktor utama, yaitu:

a. Faktor Predisposisi (predisposing factors), yaitu faktor-faktor yang mempermudah atau mempredisposisi terjadinya perilaku seseorang, antara lain pengetahuan, sikap, keyakinan, kepercayaan, nilai-nilai, tradisi dan sebagainya.

b. Faktor-faktor pemungkin (enabling factors), yaitu faktor-faktor yang memungkinkan atau yang memfasilitasi perilaku atau tindakan. Yang dimaksud dengan faktor pemungkin adalah sarana dan prasarana atau fasilitas untuk terjadinya perilaku kesehatan.

c. Faktor-faktor penguat (reinforcing factors), adalah faktor-faktor yang mendorong dan memperkuat terjadinya perilaku. 
Sehat adalah Hak Asasi Manusia, artinya "sehat" merupakan sesuatu yang sangat essensial dalam diri manusia, yang perlu dipertahankan dan dipelihara. Sehat merupakan suatu investasi untuk kehidupan yang produktif. Sehat bukannya sesuatu yang konsumtif, tetapi merupakan prasyarat agar hidup seseorang menjadi berarti, sejahtera dan bahagia. Sehat meruapakan salah satu dari tiga faktor utama yang sangat menentukan kualitas Sumber Daya Manusia, disamping pendidikan dan pendapatan (ekonomi). Kualitas SDM diukur dengan Indeks Pembangunan Manusia (Depkes, 2002).

Dalam kenyataan dimasyarakat, banyak sekali pengertian tentang sehat dan kesehatan diartikan sangat sederhana sekali sehingga petugas kesehatan harus mengetahui apa sebenarnya konsep sehat yang ada di nasyarakat tersebut. Ini penting diketahui dalam rangka mendekatkan masyarakat dalam program atau intervensi yang akan dilakukan. Pentingnya kesehatan bagi manusia dalam rangka menunjang kehidupan sehari-hari sudah tidak dapat dipungkiri lagi. Namun kadangkala manusia kurang memperhatikan bahkan tidak merasakan akan pentingnya kesehatan itu. Mereka baru mulai merasakan akan pentingnya kesehatan bila mereka telah jatuh sakit dan terbaring tidak berdaya di rumah sakit (Syahrizal, 2002).

Perilaku manusia sebagian besar ialah perilaku yang dibentuk dan dapat dipelajari. Berikut adalah cara terbentuknya perilaku seseorang (Walgito dalam Luthviatin 2012):

a. Kebiasaan, terbentuknya perilaku karena kebiasaan yang dilakukan. Misal menggosok gigi sebelum tidur, bangun pagi dan sarapan pagi.

b. Pengertian (insight), terbentuknya perilaku ditempuh dengan pengertian.

c. Penggunaan Model, pembentukan perilaku melalui contoh atau model. Model yang dimaksud adalah pemimpin, orang tua dan tokoh panutan lainnya.

Faktor-Faktor yang mempengaruhi Perilaku Hidup Bersih dan Sehat, yaitu:

\section{Tingkat Pendidikan}

Tingkat pendidikan berhubungan dengan kemampuan menerima informasi kesehatan dari media massa dan petugas kesehatan. Banyak kasus kesakitan dan kematian masyarakat diakibatkan rendahnya tingkat pendidikan penduduk. Suatu laporan dari negara bagian Kerala di India Utara menyatakan bahwa status kesehatan disana sangat baik, jauh diatas rata-rata status kesehatan nasional. Setelah ditelusuri ternyata tingkat pendidikan kaum wanitanya sangat tinggi diatas kaum pria (widoyono, 2008). 
Pendidikan dapat meningkatkan kematangan intelektual seseorang, kematangan intelektual ini berpengaruh pada wawasan, cara berfikir, baik dalam cara pengambilan keputusan maupun dalam pembuatan kebijakan. Semakin tinggi pendidikan formal, akan semakin baik pengetahuan tentang kesehatan (Hastono, 1997)

\section{Jumlah Pendapatan}

Faktor ekonomi yang berhubungan dengan daya beli masyarakat. Kemampuan ekonomi masyarakat biasanya tercermin pada kondisi lingkungan perumahan seperti sarana air minum, jamban keluarga, SPAL, lantai, dinding dan atap rumah. kemampuan anggaran rumah tangga juga mempengaruhi kecepatan untuk meminta pertolongan kesehatan apabila seseorang individu tiba-tiba saja terkena penyakit. Hal ini juga akan berdampak pada praktik perilaku hidup bersih dan sehat (Widoyono, 2008).

Daya untuk membeli makanan tergantung pada penghasilan seseorang. Perilaku konsumsi makan merupakan hasil dari interaksi antara faktor ekonomi dengan faktor sosial budaya. Faktor ekonomi berhubungan dengan tingkat pendapatan seseorang. Tingkat pendapatan akan menentukan kualitas dan kuantitas makanan yang dikonsumsi. Besarnya suatu keluarga dan tingkat pendapatan berhubungan dengan kualitas dan kuantitas makanan yang akan dikonsumsi (Mulyono Joyomartono, 2006)

\section{Jumlah Anggota Keluarga}

Keluarga adalah unit terkecil kehidupan bangsa, yang sangat diharapkan dapat mengatur, mengendalikan masalah Poleksosbudhankamka (Politik, ekonomi, sosial, budaya, ketahanan dan keamanan keluarga) yang secara berantai menuju yang lebih besar dan terakhir berskala nasional. Gerakan keluarga berencana Indonesia telah menjadi contoh bagaimana negara dengan penduduk terbesar keempat didunia dapat mengendalikan dan menerima gerakan keluarga berencana sebagai salah satu bentuk pembangunan keluarga yang lebih dapat dikendalikan untuk mencapai kesejahteraan (Manuaba, 1999).

Jumlah anggota keluarga dapat mempunyai pengaruh terhadap kesakitan (seperti penyakit menular dan gangguan gizi) dan pemanfaatan pelayanan kesehatan. Suatu keluarga besar karena besarnya tanggungan secara relatif mungkin harus tinggal berdesak-desakan didalam rumah yang luasnya terbatas hingga memudahkan penularan penyakit menular di kalangan anggota-anggotanya, karena persediaan harus digunakan untuk anggota keluarga yang 
besar maka mungkin pula dapat membeli cukup makanan yang bernilai gizi cukup atau tidak dapat memanfaatkan fasilitas kesehatan yang tersedia dan sebagainya (Soekidjo Notoatmodjo, 2003).

Banyak sedikitnya jumlah keluarga dapat memberikan sumbangan baik secara materiil maupun spritual bagi kelangsungan hidup suatu keluarga. Disamping itu juga dapat memberikan dampak pada kesehatan lingkungan maupun kesejahteraan keluarga tersebut baik positif maupun negatif (Hari Iskriyanti, 2002).

\section{Pengetahuan}

Menurut Notoatmodjo (2007), pengetahuan adalah merupakan hasil dari tahu dan ini setelah orang melakukan penginderaan terhadap obyek tertentu. Penginderaan terjadi melalui panca indera manusia, yakni indera penglihatan, pendengaran, penciuman, rasadan raba. Sebagaian besar pengetahuan manusia diperoleh melalui mata dan telinga.

\section{Sikap}

Sikap menggambarkan suka atau tidak suka seseorang terhadap suatu objek. Sikap sering diperoleh dari pengalaman sendiri atau dari orang lain yang paling dekat. Sikap membuat seseorang mendekati atau menjauhi orang lain maupun objek lain. Sikap positif terhadap nilai-nilai kesehatan tidak selalu terwujud dalam suatu tindakan nyata. Hal ini disebabkan oleh beberapa alasan, antara lain:

a. Sikap akan terwujud di dalam suatu tindakan tergantung pada situasi saat itu.

b. Sikap akan diikuti atau tidak diikuti oleh tindakan yang mengacu kepada pengalaman orang lain.

c. Sikap diikuti atau tidak diikuti oleh suatu tindakan berdasarkan pada banyak atau sedikitnya pengalaman seseorang.

d. Nilai(Value)

Didalam suatu masyarakat apapun selalu berlaku nilai-nilai yang menjadi pegangan setiap orang dalam menyelenggarakan hidup bermasyarakat.

Perilaku hidup bersih sehat (PHBS) adalah upaya untuk memberikan pengalaman belajar atau menciptakan suatu kondisi bagi perorangan, keluarga, kelompok dan masyarakat, dengan membuka jalur komunikasi, memberikan informasi dan melakukan edukasi untuk meningkatkan pengetahuan, sikap dan perilaku melalui pendekatan pimpinan (advocacy), bina suasana (social support) dan pemberdayaan masyarakat 
(empowerment). Masyarakat dapat mengenali dan mengatasi masalahnya sendiri, dan dapat menerapkan cara- cara hidup sehat dengan menjaga, memelihara dan meningkatkan kesehatannya (Notoatmodjo,2007).

Manfaat Prilaku hidup bersih dan sehat (PHBS) yaitu :

a. Manfaat PHBS bagi rumah tangga :

Setiap rumah tangga meningkatkan kesehatannya dan tidak mudah sakit. Anak tumbuh sehat dan cerdas, Produktivitas kerja anggota keluarga meningkat dengan meningkatnya kesehatan anggota rumah tangga, maka biaya yang dialokasikan untuk kesehatan dapat dialihkan untuk biaya investasi seperti biaya pendidikan, pemenuhan gizi keluarga dan modal usaha untuk peningkatan pendapatan keluarga (Putranto, 2006).

b. Manfaat PHBS bagi masyarakat :

Masyarakat mampu mengupayakan lingkungan yang sehat Masyarakat mampu mencegah dan menanggulangi masalahmasalah kesehatan Masyarakat memamnfaatkan pelayanan kesehatan yang ada Masyarakat mampu mengembangkan upaya kesehatan bersumber masyarakat (UKBM) seperti posyandu, jaminan pemeliharaan kesehatan, tabungan bersalin (tabulin), arisan jamban, kelompok pemakai air, ambulan desa dan lain-lain. Sasaran PHBS di Tumah Tangga adalah seluruh anggota keluarga, yaitu :

a) Pasangan usia subur

b) Ibu hamil dan menyusui

c) Anak dan remaja

d) Usia lanjut

e) Pengasuh anak

\section{METODE PENELITIAN}

Penelitian ini termasuk jenis penelitian survey analitik dengan pendekatan Cross Sectional karena penelitian ini bertujuan untuk mengetahui factor penyebab terhadap suatu kejadian perilaku. Survei analitik adalah survey atau penelitian yang mencoba menggali bagaimana dan mengapa fenomena kesehatan itu terjadi, kemudian melakukan analisis dinamika korelasi antara fenomena (Notoatmojo S, 2010).

1. Analisa Univariat

Mendeskripsikan hasil distribusi frekuensi dan persentase dari variabel de[endent yaitu penerapan perilaku hidup bersih dan sehat. Serta mendeskripsikan hasil distribusi frekuensi variabel independent pada penelitian ini yaitu tingkat pendidikan, jumlah Pendapatan, jumlah anggota keluarga, pengetahuan dan sikap. 
2. Analisa Bivariat

Dalam penelitian ini analisis bivariat dilakukan untuk mengetahui hubungan antar variabel independent (tingkat pendidikan, jumlah Pendapatan, jumlah anggota keluarga, pengetahuan dan sikap) dengan variabel dependent (perilaku hidup bersih dan sehat). Uji statistik yang digunakan adalah Chi Square.

3. Analisa Multivariat

Analisis multivariat yang digunakan adalah regresi logistik model prediksi, dengan tingkat kepercayaan $95 \%$ dan menggunakan metode menentukan odds rasio variabel kategorik polikontom dengan salah satu kategori menjadi pembanding dengan cara chi square.

\section{HASIL DAN PEMBAHASAN}

\section{Analisis Univariat}

Tabel 1. Gambaran Perilaku Hidup Bersih dan Sehat, Tingkat Pendidikan, Jumlah Pendapatan, Jumlah Anggota Keluarga, Pengetahuan dan Sikap Responden

\begin{tabular}{|c|c|c|c|}
\hline No & Variabel & $\mathbf{n}$ & $\%$ \\
\hline \multirow[t]{3}{*}{1} & Perilaku Hidup Bersih dan Sehat & & \\
\hline & Baik & 64 & 65,3 \\
\hline & Kurang Baik & 34 & 34,7 \\
\hline \multirow[t]{3}{*}{2} & Tingkat Pendidikan & & \\
\hline & Tinggi & 34 & 34,7 \\
\hline & Rendah & 64 & 65,3 \\
\hline \multirow[t]{3}{*}{3} & Jumlah Pendapatan & & \\
\hline & Tnggi ( $\geq 2.063 .000)$ & 43 & 43,9 \\
\hline & Rendah $(<2.063 .000)$ & 55 & 56,1 \\
\hline \multirow[t]{3}{*}{4} & Jumlah Anggota Keluarga & & \\
\hline & Keluarga Kecil ( $₫ 4$ ) & 54 & 55,1 \\
\hline & Keluarga Besar (>4) & 44 & 44,9 \\
\hline \multirow[t]{3}{*}{5} & Pengetahuan & & \\
\hline & Baik & 96 & 98 \\
\hline & Buruk & 2 & 2 \\
\hline \multirow[t]{3}{*}{6} & Sikap & & \\
\hline & Positif & 59 & 60,2 \\
\hline & Negatif & 39 & 39,8 \\
\hline
\end{tabular}


2. Analisa Bivariat

Tabel 2. Hubungan Tingkat Pendidikan dengan Perilaku Hidup Bersih dan Sehat Responden

\begin{tabular}{|c|c|c|c|c|c|c|c|c|}
\hline \multirow{3}{*}{ Pendidikan } & \multicolumn{4}{|c|}{$\begin{array}{l}\text { Perilaku Hidup Bersih dan } \\
\text { Sehat }\end{array}$} & \multirow{3}{*}{$\begin{array}{c}\text { Total } \\
\mathrm{N} \\
\end{array}$} & \multirow{3}{*}{$\%$} & \multirow{3}{*}{ p-value } & \multirow{3}{*}{$\begin{array}{c}\text { PR } \\
95 \% \mathrm{CI}\end{array}$} \\
\hline & \multicolumn{2}{|c|}{ Baik } & \multicolumn{2}{|c|}{ Kurang Baik } & & & & \\
\hline & $\mathbf{n}$ & $\%$ & $\mathbf{n}$ & $\%$ & & & & \\
\hline Tinggi & 19 & 55,9 & 15 & 44,1 & 34 & 100 & 0,228 & $\begin{array}{c}0,535 \\
(0,225- \\
1,268)\end{array}$ \\
\hline Rendah & 45 & 70,3 & 19 & 29,7 & 64 & 100 & & \\
\hline
\end{tabular}

Berdasarkan tabel diatas, dapat dilihat bahwa dari 34 responden berpendidikan tinggi yang mempunyai perilaku hidup bersih dan sehat kurang baik sebanyak $15(44,1 \%)$ responden. Sedangkan dari 64 responden berpendidikan rendah yang berprilaku hidup bersih dan sehat kurang baik sebanyak 19 (29,7\%) responden. Dari data tersebut tampak Proporsi responden yang paling banyak menerapkan PHBS dengan baik adalah pada kategori responden yang berpendidikan rendah. Hasil statistik menunjukkan bahwa pendidikan warga di wilayah kerja Puskesmas Simpang IV Sipin tidak memiliki hubungan dengan penerapan PHBS ( $p$-value $=0,228>\alpha$ ).

Tabel 3. Hubungan Jumlah Pendapatan dengan Perilaku Hidup Bersih dan Sehat

\begin{tabular}{|c|c|c|c|c|c|c|c|c|}
\hline \multirow{3}{*}{$\begin{array}{c}\text { Jumlah } \\
\text { Pendapatan }\end{array}$} & \multicolumn{4}{|c|}{$\begin{array}{c}\text { Perilaku Hidup Bersih dan } \\
\text { Sehat } \\
\end{array}$} & \multirow[t]{2}{*}{ Total } & \multirow{3}{*}{$\%$} & \multirow{3}{*}{$\begin{array}{l}\text { p- } \\
\text { val } \\
\text { ue }\end{array}$} & \multirow{3}{*}{$\begin{array}{c}\text { PR } \\
95 \% \text { CI }\end{array}$} \\
\hline & \multicolumn{2}{|c|}{ Baik } & \multicolumn{2}{|c|}{ Kurang Baik } & & & & \\
\hline & $\mathbf{n}$ & $\%$ & $\mathbf{n}$ & $\%$ & $\mathbf{N}$ & & & \\
\hline Tinggi & 27 & 62,8 & 16 & 37,2 & 43 & 100 & $\begin{array}{l}0,8 \\
04\end{array}$ & $\begin{array}{c}0,821 \\
(0,356- \\
1,895)\end{array}$ \\
\hline Rendah & 27 & 67,3 & 18 & 32,7 & 55 & 100 & & \\
\hline
\end{tabular}

Berdasarkan tabel 5.3 diatas dapat dilihat Warga di wilayah kerja Puskesmas Simpang IV Sipin yang memiliki jumlah pendapatan rendah $(<2.063 .000)$ lebih banyak menerapkan PHBS, yaitu dengan proporsi sebesar $67,3 \%$. Hasil statistik menunjukkan bahwa jumlah pendapatan tidak memiliki hubungan dengan penerapan PHBS ( $\mathrm{p}$ value $=0,804)$.

Tabel 4. Hubungan Jumlah Anggota Keluarga dengan Perilaku Hidup Bersih dan Sehat

\begin{tabular}{|c|c|c|c|c|c|c|c|c|}
\hline \multirow{3}{*}{$\begin{array}{c}\text { Jumlah } \\
\text { Anggota } \\
\text { Keluarga }\end{array}$} & \multicolumn{4}{|c|}{$\begin{array}{l}\text { Perilaku Hidup Bersih dan } \\
\text { Sehat }\end{array}$} & \multirow{3}{*}{$\begin{array}{l}\text { To } \\
\text { tal } \\
\mathrm{N} \\
\end{array}$} & \multirow{3}{*}{$\%$} & \multirow{3}{*}{$\begin{array}{c}\mathrm{p}- \\
\text { value }\end{array}$} & \multirow{3}{*}{$\begin{array}{c}\text { PR } \\
95 \% \mathrm{CI}\end{array}$} \\
\hline & \multicolumn{2}{|c|}{ Baik } & \multicolumn{2}{|c|}{ Kurang Baik } & & & & \\
\hline & $\mathrm{n}$ & $\%$ & $\mathrm{n}$ & $\%$ & & & & \\
\hline $\begin{array}{r}\text { Keluarga } \\
\text { Kecil }\end{array}$ & 38 & 70,4 & 16 & 29,6 & 54 & 100 & $\begin{array}{c}0,34 \\
0\end{array}$ & $\begin{array}{c}1,644 \\
(0,711-3,801)\end{array}$ \\
\hline $\begin{array}{l}\text { Keluarga } \\
\text { Besar }\end{array}$ & 26 & 59,1 & 18 & 40,9 & 44 & 100 & & \\
\hline
\end{tabular}


Berdasarkan tabel diatas dapat diketahui bahwa Kategori jumlah anggota keluarga responden tergambar bahwa responden yang paling banyak menerapkan PHBS adalah responden yang memiliki keluarga kecil atau di dalam rumah tangga terdiri dari $\leq 4$ dengan proporsi $70,4 \%$. Hasil statistik menunjukkan bahwa jumlah anggota keluarga tidak memiliki hubungan dengan penerapan PHBS ( $\mathrm{p}$ value=0,340).

Tabel 5. Hubungan Pengetahuan dengan Perilaku Hidup Bersih dan Sehat

\begin{tabular}{|c|c|c|c|c|c|c|c|c|}
\hline \multirow{3}{*}{ Pengetahuan } & \multicolumn{4}{|c|}{ Perilaku Hidup Bersih dan Sehat } & \multirow{3}{*}{$\begin{array}{c}\text { Total } \\
\mathrm{N}\end{array}$} & \multirow{3}{*}{$\%$} & \multirow{3}{*}{$\begin{array}{c}\text { p- } \\
\text { value }\end{array}$} & \multirow{3}{*}{$\underset{95 \% \mathrm{CI}}{\mathrm{PR}}$} \\
\hline & \multicolumn{2}{|c|}{ Baik } & \multicolumn{2}{|c|}{ Kurang Baik } & & & & \\
\hline & $\mathbf{n}$ & $\%$ & $\mathbf{N}$ & $\%$ & & & & \\
\hline Baik & 63 & 65,6 & 33 & 34,4 & 96 & 100 & 1,000 & $\begin{array}{c}1,909 \\
(0,116- \\
31,508)\end{array}$ \\
\hline Kurang & 1 & 50 & 1 & 50 & 2 & 100 & & \\
\hline
\end{tabular}

Berdasarkan tabel 5. diatas Hasil uji statistik menunjukkan bahwa pengetahuan tidak memiliki hubungan dengan penerapan PHBS di wilayah kerja Puskesmas Simpang IV Sipin ( $p$ value=1,000). Selain itu respoden yang memiliki pengetahuan yang baik tentang PHBS lebih banyak menerapkan PHBS daripada yang memiliki pengetahuan PHBS kurang baik $(65,6 \%)$.

Tabel 6. Hubungan Sikap dengan Perilaku Hidup Bersih dan Sehat

\begin{tabular}{|c|c|c|c|c|c|c|c|c|}
\hline \multirow{3}{*}{ Sikap } & \multicolumn{4}{|c|}{ Perilaku Hidup Bersih dan Sehat } & \multirow{3}{*}{$\begin{array}{c}\text { Total } \\
\mathrm{N}\end{array}$} & \multirow{3}{*}{$\%$} & \multirow{3}{*}{$\begin{array}{c}\text { p- } \\
\text { value }\end{array}$} & \multirow{3}{*}{$\begin{array}{c}\text { PR } \\
95 \% \mathrm{CI}\end{array}$} \\
\hline & \multicolumn{2}{|c|}{ Baik } & \multicolumn{2}{|c|}{ Kurang Baik } & & & & \\
\hline & $\mathbf{n}$ & $\%$ & $\mathbf{n}$ & $\%$ & & & & \\
\hline Positif & 42 & 71,2 & 17 & 28,8 & 59 & 100 & 0,198 & $\begin{array}{c}1,909 \\
(0,818- \\
4,455)\end{array}$ \\
\hline Negatif & 22 & 56,4 & 17 & 43,6 & 39 & 100 & & \\
\hline
\end{tabular}

Berdasarkan tabel 6. diatas dapat dilihat Hasil statistik menunjukkan bahwa sikap positif menjadi faktor yang memiliki proporsi terbesar $(71,2 \%)$ dalam menerapkan PHBS di wilayah kerja Puskesmas Simpang IV Sipin. Nilai statistik PR=1,909 memiliki arti bahwa sikap yang masuk kategori positif dapat meningkatkan penerapan PHBS di wilayah kerja Puskesmas Simpang IV Sipin. Rentang CI yang ada menunjukkan bahwa di populasi luas, sikap yang positif bisa menurunkan atau menaikan angka penerapan PHBS. Namun diperlukan sampel yang lebih besar untuk mendeteksi hubungan antara kedua faktor tersebut. 


\section{Analisis Multivariat}

Analisa multivariat dilakukan untuk mengetahui variabel independen (Tingkat pendidikan, jumlah pendapatan, jumlah anggota keluarga, pengetahuan dan sikap) mana yang paling besar pengaruhnya terhadap variabel dependen (Perilaku hidup bersih dan sehat). Analisa multivariat bertujuan mendapatkan model terbaik dalam menentukan variabel mana yang paling menentukan dalam penerapan hidup bersih dan sehat. Langkah-langkah yang dilakukan adalah :

\section{a. Seleksi Bivariat}

Pemilihan variabel kandidat dilakukan melalui analisi bivariat. Hasil uji bivariat mempunyai nilai $\mathrm{p} \leq 0,25$ maka variabel tersebut dapat masuk kedalam model multivariat, sedangkan variabel yang mempunyai nilai $p>0,25$ tidak diikutsertakan dalam analisis multivariat. Dalam variabel ini ada 3 variabel yang masuk dalam analisis multivariat yaitu tingkat pendidikan, jumlah anggota keluarga dan sikap. Variabel jumlah pendapatan dan pengetahuan $>0,25$, namun karena kedua variabel tersebut dianggap penting maka tetap dimasukkan ke dalam pemodelan.Seperti pada tabel dibawah ini :

Tabel 7. Variabel Independen yang Masuk Kandidat Seleksi Bivariat

\begin{tabular}{|l|c|}
\hline \multicolumn{1}{|c|}{ Variabel } & P value \\
\hline Tingkat Pendidikan & 0,156 \\
\hline Jumlah Pendapatan & 0,644 \\
\hline Jumlah Anggota Keluarga & 0,245 \\
\hline Pengetahuan & 0,651 \\
\hline Sikap & 0,135 \\
\hline
\end{tabular}

Tabel 8. Model Akhir Tingkat Pendidikan, Jumlah Pendapatan, Jumlah Anggota Keluarga dan Sikap Responden Terhadap Penerapan PHBS

\begin{tabular}{lcccc}
\hline \multirow{2}{*}{ Variabel } & \multirow{2}{*}{ p value } & \multirow{2}{*}{ PR } & \multicolumn{2}{c}{ 95\% CI } \\
\cline { 5 - 6 } & & & Min & Maks \\
\hline Tingkat Pendidikan & 0,134 & 0,484 & 0,188 & 1,250 \\
IPendapatan & 0,394 & 0,668 & 0,264 & 1,690 \\
NAnggota Klg & 0,124 & 2,044 & 0,821 & 5,088 \\
Sikap & 0,087 & 2,223 & 0,890 & 5,557 \\
\hline
\end{tabular}

Berdasarkan tabel diatas dapat diketahui Hasil akhir pemodelan multivariat menunjukkan tidak ada variabel yang berhubungan dengan penerapan PHBS di wilayah kerja Puskesmas Simpang IV Sipin. Diketahui bahwa jumlah anggota keluarga yang $\leq 4$ orang dapat meningkatkan penerapan PHBS sebesar 2,044 kali lebih besar 
daripada jumlah anggota keluarga yang $>4$ orang. Kemudian warga yang memiliki sikap positif merupakan faktor risiko dan dapat meningkatkan penerapan PHBS di wilayah kerja Puskesmas Simpang IV Sipin sebesar 2,044 kali lebih besar daripada warga yang memiliki sikap negatif. Sedangkan faktor risiko yang paling mempengaruhi penerapan PHBS dalam penelitian ini adalah sikap. Sedangkan variabel yang menurunkan penerapan PHBS adalah tingkat pendidikan yang tinggi dan jumlah pendapatan yang tinggi.

\section{KESIMPULAN}

1. Tidak ada hubungan antara tingkat pendidikan dengan perilaku hidup bersih dan sehat di wilayah kerja Puskesmas Simpang IV Sipin, namun Setelah variabel pendidikan dikeluarkan, terdapat perubahan PR > 10\%, maka variabel pendidikan adalah variabel confounding.

2. Tidak ada hubunganantara jumlah pendapatan dengan perilaku hidup bersih dan sehat di wilayah kerja Puskesmas Simpang IV Sipin, namun Setelah variabel pendidikan dikeluarkan, terdapat perubahan PR > 10\%, maka variabel pendidikan adalah variabel confounding.

3. Tidak ada hubungan antara jumlah anggota keluarga dengan perilaku hidup bersih dan sehat di wilayah kerja Puskesmas Simpang IV Sipin, namun Setelah variabel pendidikan dikeluarkan, terdapat perubahan PR $>10 \%$, maka variabel pendidikan adalah variabel confounding.

4. Tidak ada hubungan antara pengetahuan dengan perilaku hidup bersih dan sehat di wilayah kerja Puskesmas Simpang IV Sipin.

5. Tidak ada hubungan antara sikap dengan perilaku hidup bersih dan sehat di wilayah kerja Puskesmas Simpang IV Sipin, namun Setelah variabel pendidikan dikeluarkan, terdapat perubahan PR $>10 \%$, maka variabel pendidikan adalah variabel confounding.

Bagi Puskesmas Simpang IV Sipin diharapkan lebih meningkatkan upaya pelayanan tenaga kesehatan, pemberian informasi dan promosi kesehatan tentang penerapan hidup bersih dan sehat, serta hasil penelitian ini dapat memberikan masukan dalam menyusun rencana strategi serta pelaksanaan dalam memberikan pelayanan tentang penerapan perilaku hidup bersih dan sehat dapat lebih di tingkatkan. Bagi Masyarakat diharapkan dapat meningkatkan kesadaran dalam penerapan perilaku hidup bersih dan sehat. 


\section{DAFTAR PUSTAKA}

Achmadi, UF. 2008. Manajemen Penyakit Berbasis Wilayah. UIPress: Jakarta. . 2006. Imunisasi Mengapa Perlu?. PT. Kompas Media Nusantara: Jakarta.

Almatsier, S. 2003. Prinsip Dasar Ilmu Gizi. Gramedia Pustaka Utama: Jakarta.

Badan Kependudukan dan Keluarga Berencana Nasional. 2012. Survei Demografi dan Kesehatan Indonesia. BKKBN: Jakarta.

Cahyati, WH dan Dina, NAN. 2012. Buku Ajar Biostatistika Inferensial. JurIKM UNNES: Semarang.

Badan Pusat Statistik. 2001. Statistik Perumahan dan Pemukiman. Hasil Survei Sosial Ekonomi Nasional: Jakarta.

Departemen Kesehatan RI. 2006. Perilaku Hidup Bersih dan Sehat di Rumah Tangga. Pusat Promosi Kesehatan: Jakarta. .2006. Pedoman Pengendalian Penyakit Infeksi Saluran Pernafasan Akut. Direktorat Jendral PPM \&PL: Jakarta. 2008. Riset Kesehatan Dasar Laporan Provinsi Jawa Tengah 2007. Badan Penelitian dan Pengembangan Kesehatan: Jakarta. .2009. Pedoman Pengendalian Penyakit Infeksi Saluran Pernapasan Akut, Direktorat Jendral P2PL: Jakarta.

Dinas Kesehatan Provinsi Jambi. 2011. Profil Kesehatan Provinsi Jambi 2011. Dinkes: Jambi. .2012. Profil Kesehatan Provinsi Jawa Tengah tahun2012.

Hastono, SP. 2008. Analisis Data Kesehatan Fakultas Kesehatan Masyarakat. Universitas Indonesia: Depok.

Hidayat, AA. 2009. Metode Penelitian Keperawatan dan Teknik Analisis Data. Salemba Medika: Jakarta.

Jasenak, Metal. 2011. Recurrent Respiratory Infectionsin Children: Definition, Diagnostic Approach, Treatment and Prevention. Slovak Republic.

Kementrian Kesehatan RI. 2010. Profil Kesehatan. Pusat Data dan Informasi: Jakarta.

2011. Rencana Aksi Program Pengendalian Penyakit dan Penyehatan Lingkungan tahun 2010-2014. Direktorat Jendral P2PL: Jakarta. 2012. Laporan Akuntabilitas Kinerja Kementrian Kesehatan 2012. Jakarta.

2013. Profil Kesehatan Indonesia 2012. Departemen Kesehatan Republik Indonesia: Jakarta.

Kusnoputranto H, Dewi S. 2000. Kesehatan Lingkungan. Universitas Indonesia: Depok. 
Murti, B. 2003. Prinsip dan Metode Riset Epidemiologi. Gadjah Mada University Press: Yogyakarta.

Notoatmodjo, S. 2007. Kesehatan Masyarakat: Ilmu dan Seni. Rineka Cipta: Jakarta. 2010. Metodologi Penelitian Kesehatan (Edisi Revisi). Rineka Cipta: Jakarta.

Proverawati, A dan Eni R .2012. Perilaku Hidup Bersih dan Sehat (PHBS). Nuha Medika: Yogyakarta.

Riyanto, A. 2012. Penerapan Analisis Multivariat dalam Penelitian Kesehatan. Nuha Medika: Yogyakarta.

Sastroasmoro, S. 2005. Dasar-Dasar Metodologi Penelitian Klinis. Binarupa Aksara: Jakarta.

Soekanto, Soerjono. 2002. Sosiologi suatu pengantar. Raja Grafindo Persada: Jakarta.

Sopiyudin, MD. 2009. Statistik untuk Kedokteran dan Kesehatan, Salemba Medika: Jakarta. 